
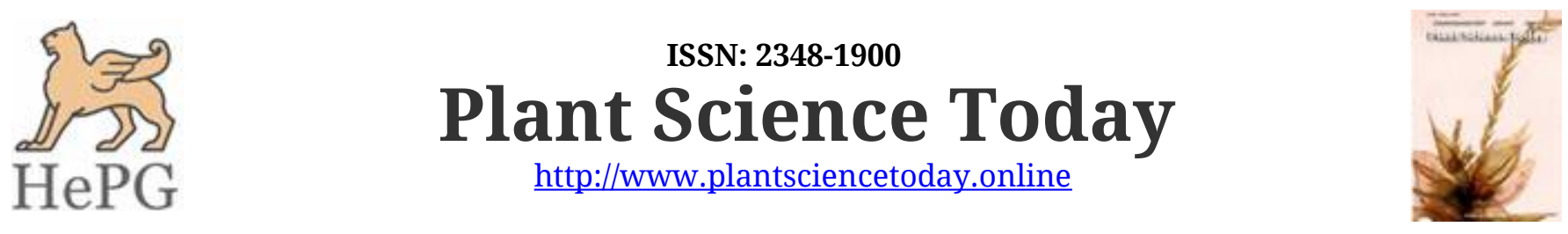

Review Article

\title{
Nociception and herbal plants: A review on the most important herbal plants effective on chronic pain
}

\author{
Parisa Arvin ${ }^{1,2}$, Saber Abbaszadeh ${ }^{2,3} \&$ Mojtaba Khaksarian $^{4^{*}}$ \\ ${ }^{1}$ Department of Physiology, Faculty of Medicine, Homozgan University of Medical Sciences, Bandar Abbas, Iran \\ ${ }^{2}$ Razi Herbal Medicines Research Center, Lorestan University of Medical Sciences, Khorramabad, Iran \\ ${ }^{3}$ Student Research Committee, Lorestan University of Medical Sciences, Khorramabad, Iran \\ ${ }^{4}$ Razi Herbal Medicines Research Center \& Physiology Department, School of Medicine, Lorestan University of Medical Sciences, \\ Khorramabad, Iran
}

\section{Article history}

Received: 18 May2019

Accepted: 21 June 2019

Published: 01 October 2019

\section{Publisher}

Horizon e-Publishing Group

\section{*Correspondence}

Mojtaba Khaksarian

$凶$ mojkhaksar@yahoo.com

\begin{abstract}
Chronic pain can be periodic, persistent, or even a combination of both. Unlike acute pain, chronic pain is not usually useful, reduces the quality of life and functional abilities and also weakens mental health, interpersonal relationships, and financial status, leading to changes in appetite, sleep disorders, psychomotor retardation, tiredness and depression. Human being has always faced various kinds of pain during life and sought to relieve his pain. Pain is a sign of a disease that acts as a warning mechanism and informs of a tissue injury. In this regard, the analgesic effects of many medicinal plants have also been studied. Therefore, in this review study, indigenous medicinal plants with anti-chronic pain effects were reported. Information to conduct this review was obtained using the keywords chronic pain, herbal drug, Iran, medicinal plants, extracts and essential oils to retrieve articles indexed in databases such as Scopus, SID, Magiran, Google Scholar and other Persian databases. The related articles were reviewed for plants serving as chronic pain killers. After reviewing the literature, it was found that Solanum melongena, Hyoscyamus niger, Phoenix dactylifera, Cinnamomum zeylanicum, Artemisia sieberi, Crocus sativus, Carum copticum, Euphorbia helioscopia, Hypericum perforatum, Cucurbita maxima, Passiflora caerulea, Rosa damascena, Tanacetum parthenium, Allium jesdianum and Pistacia atlantica among indigenous medicinal plants with analgesic effect.
\end{abstract}

Keywords: Pain; Chronic pain; Medicinal plants; Iran

Citation: Arvin P, Abbaszadeh S, Khaksarian M. Nociception and herbal plants: A review on the most important herbal plants effective on chronic pain. Plant Science Today 2019;6(4):383-388. https://doi.org/10.14719/pst.2019.6.4.572

Copyright: ( ) Arvin et al (2019). This is an open-access article distributed under the terms of the Creative Commons Attribution License, which permits unrestricted use, distribution, and reproduction in any medium, provided the original author and source are credited (https://creativecommons.org/licenses/by/4.0/).

Indexing: Plant Science Today is covered by Scopus, Web of Science, BIOSIS Previews, ESCI, CAS, AGRIS, CABI, Google Scholar, etc. Full list at http://www.plantsciencetoday.online

\section{Introduction}

Pain is an unpleasant feeling caused by tissue injury, and if not treated, it can prevent the daily activities of life $(1,2)$. Pain is a physiological response to an annoying trigger, which everyone has experienced in his/her personal life. Most people complain of pain in their daily lives or in hospitals, so that pain is the main reason for referral to the emergency (3-5). Chronic pain is associated with other topics such as slow burning 
pain, vague pain, pulsatile pain and nausea pain. Chronic pain is felt after one second or more and then slowly intensifies in a few seconds, and sometimes even up to one minute later. The origin of chronic pain can be neurogenic, nociceptive, psychotic or unknown. It can also be periodic, persistent or even a combination of both. In contrary to acute pain, chronic pain is not usually useful, reduces the quality of life and functional abilities and also weakens mental health, interpersonal relationships and financial status. In addition, chronic pain can lead to changes in appetite, sleep disorders, psychomotor retardation, mood disorder, fear of the community, and depression $(6,7)$. Pain is considered a symptom of a disease that acts as a warning mechanism and informs of a tissue injury (8). Regardless of the origin of the disease, today pain is the most common discomfort of human communities, especially in industrialized countries and developing countries $(9,10)$. Pain can be caused by damage to tissues by harmful stimuli such as chemical, electrical, thermal, and mechanical stimuli, and can be acute and chronic (11). Throughout his life, man has always faced various kinds of pain and has sought to relieve his pain. After the synthesis of chemical analgesic drugs, their entry into the market and their extensive use to relieve pain, their side effects also appeared. For example, opioids also appear to cause nausea, respiratory weakness, constipation, and in case of being taken in the long term, addiction (12). For the treatment of pain in the recent century, nonsteroidal anti-inflammatory drugs and opioids have been extensively used that lead to side effects $(13,14)$. The use of medicinal plants to relieve pain has a long history in the world of medicine and in Iran, and given that the use of herbal drugs at the conventional doses has lesser risks than synthetic drugs, the attention of researchers has been drawn to the use of medicinal plants. One of the earliest methods of coping with diseases is the traditional use of medicinal plants. Many plant herbs are herbs that are always available and are easy to use and consuming, including ginger, turmeric, peppermint, spicy pepper and a number of other herbs. These have been used for pain relief in Iran since ancient times. Plants and materials extracted from them are used to treat various diseases such as infectious, non-infectious and chronic diseases in humans (15-21). Today, due to the lower side effects of medicinal plants, the tendency to use them is increasing. In this regard, the analgesic effects of many medicinal plants have also been studied $(22,23)$. In this review study, indigenous medicinal plants with anti-chronic pain effects were reported.

\section{Methodology}

Information to conduct this review was obtained using the keywords chronic pain, herbal drug, Iran, medicinal plants, extracts and essential oils to retrieve articles indexed in databases such as Scopus, Google Scholar, SID, Magiran and other Persian databases. The related articles were reviewed for plants serving as analgesic.

\section{Results}

After reviewing the literature, it was found that Solanum melongena L., Hyoscyamus niger L., Phoenix dactylfera L., Cinnamomum zeylanicum J.Presl, Artemisia sieberi Besser, Crocus sativus L., Carum copticum (L.) C. B. Clarke, Euphorbia helioscopia L., Hypericum perforatum L., Cucurbita maxima Duchesne, Passiflora caerulea L., Rosa damascena Mill., Tanacetum parthenium (L.) Sch. Bip., Allium jesdianum Boiss. \& Buhse and Pistacia atlantica Desf., among indigenous medicinal plants with analgesic effect were the most important.

\section{Solanum melongena $\mathrm{L}$.}

The results of a study that investigated the antichronic pain effect of hydroalcoholic extract of $S$. melongena in mouse model, showed that the extract of $S$. melongena at a dose of $1000 \mathrm{mg} / \mathrm{kg}$ of formalin test reduced the pain of chronic phase, with a significant difference between 20 min and $40 \mathrm{~min}$ intervals compared to the control group (24).

\section{Hyoscyamus niger $\mathrm{L}$.}

Statistical analysis of the data of a study showed that injection of hydroalcoholic extract of Hyoscyamus niger seeds in studied doses (500, 1000 and $2000 \mathrm{mg} / \mathrm{kg}$ ) decreased the pain due to formalin test in male rats compared to the control group (25).

\section{Phoenix dactylifera $\mathrm{L}$.}

The results of one study showed that the longterm effects of aqueous extract of $10 \% P$. dactylifera in the chronic phase of formalin test in male rat model showed significant analgesic effects compared to the control group (26). The results of formalin test in the study of the analgesic effect of hydroalcoholic extract of $P$. dactylifera in the mouse model showed that the mean pain severity in the formalin test in the control group was $0.0599 \pm 1.665$ and at 2, 20 and $200 \mathrm{mg}$ of the extract $0.660 \pm 1.079,0.0822 \pm$ 0.9192 and $0.0658 \pm 0.3842$, respectively (32).

\section{Cinnamomum zeylanicum J.Presl}

The results of a study investigating the effect of cinnamon extract on the chronic pain of large mice using formalin test showed that this extract reduced the second stage of pain (chronic pain) at a dose of $50 \mathrm{mg} / \mathrm{kg}$ significantly compared to the control group. The results of that study confirmed the chronic analgesic effect of highdose cinnamon in formalin test, and it seemed that this effect was due to the anti-inflammatory effect of the plant (27). 


\section{Artemisia sieberi Besser}

The results of one study on the effect of hydroalcoholic extract of $A$. sieberi on mice showed that the analgesic effect of the extract in chronic pain phase was more pronounced, with analgesic effect of $4000 \mathrm{mg} / \mathrm{kg}$ of $A$. sieberi being higher than morphine $2 \mathrm{mg} / \mathrm{kg}$ (28).

\section{Crocus sativus $\mathrm{L}$.}

The results of one study on the anti-chronic pain effect of aqueous extract of Crocus sativus showed that an extract of $C$. sativus flower with 10,50 and $100 \mathrm{mg} / \mathrm{kg}$ doses in laboratory mice showed analgesic effects (29).

\section{Carum copticum (L.) C. B. Clarke}

The analgesic effects of alcoholic Carum copticum extract on chronic pain in mice with intraperitoneal injection of $C$. copticum extract $(400 \mathrm{mg} / \mathrm{kg})$ with different concentrations of morphine sulfate ( 1 and $2 \mathrm{mg} / \mathrm{kg}$ ) showed that Carum copticum in the first phase had no effect on formalin-induced pain, which was considered as a type of acute pain, but its effect on the second phase of formalin-induced pain, which was a chronic pain, was significant (30).

\section{Euphorbia helioscopia L.}

The results of one study on mice showed that there was a significant difference between the extract of $8 \mathrm{mg}$ in the chronic pain phase compared to the control group (31).

\section{Hypericum perforatum $\mathrm{L}$.}

The results of one study showed that the aqueous extract of $H$. perforatum at 200, 400 and $800 \mathrm{mg} / \mathrm{kg}$ of body weight of male anesthetized rats increased in the chronic phase of formalin test, but sodium salicylate was effective only on the second phase of formalin test (33).

\section{Cucurbita maxima Duchesne}

The results of one study showed that the hydroalcoholic extract of $C$. maxima at doses of 50,100 and $200 \mathrm{mg} / \mathrm{kg}$ caused significant chronic pain in the rat compared to the control group (34).

\section{Passiflora caerulea $\mathrm{L}$.}

The results of one study showed that methanolic extract of $P$. caerulea at doses ranging from 80 to $300 \mathrm{mg} / \mathrm{kg}$ had significant inhibitory effects on the chronic phase response of formalin test and writhing test, although an increase was seen after the extract treatment at the time of tail jerk. This was lower than the effect induced by morphine compared to the controls (35).

\section{Rosa damascena Mill.}

The results of one study showed that inhaling rose extract on the emotional and emotional dimension of pain in women and men was not effective. Meanwhile, the inhalation of $R$. damascena extract on the sensory dimension was significantly different between men and women, but the emotional dimension was not different between women and men (36).

\section{Tanacetum parthenium (L.) Sch. Bip.}

The results of one study showed that the ethanolic extract of $T$. parthenium in the experimental small mice was significantly more effective in the formalin model at a dose of $10 \mathrm{mg} / \mathrm{kg}$ body weight on the chronic phase of the pain, and a significant difference was observed between the groups of ibuprofen and distilled water (37).

\section{Allium jesdianum Boiss. \& Buhse}

In this study, we showed that $A$. jesdianum acts on COX activity and can be used to control prostaglandins. Our results showed that both $A$. jesdianum material and extract could inhibit COX-1 and partially inhibit COX-2, although these effects were not observed at the lowest dose. Despite the difference in COX inhibitory levels, both of the studied plant species had inhibitory effects, although showed little effect but significant (63).

\section{Pistacia atlantica Desf.}

$P$. atlantica fruit extract $1.66 \mathrm{~g} / \mathrm{kg}$ and the maximum non-fatal doses were $0.93 \mathrm{~g} / \mathrm{kg}$. The results revealed that in hot plate and tail-flick tests, $P$. atlantica fruit extract at the doses of 50,150 and $350 \mathrm{mg} / \mathrm{kg}$ had an analgesic effect as dosedependent, 30 minutes after administration (64).

\section{Discussion}

Pain is one of the phenomena that every human being faces during his lifetime and is a warning factor, but it is, anyway, an unpleasant feeling, and human beings have sought a way to deal with it. It can be said that the pain is a response consisting of sensory, emotional and affective constituents. The disease, inflammation, and damage to the central and peripheral nervous system cause significant changes in pain pathways such as increased irritability and gene expression. Suffering from certain pains in the long term will impose undesirable mental and psychological effects on the individual. For this reason, humans have always sought to find a solution to eliminate or reduce pain (38). It has been shown that the Tanacetum parthenium produces an analgesic effect via affecting inflammatory processes (38). Eggplant exerts its effect through peripheral analgesic mechanism and cholinergic pathways (39). The bang grain plant exhibits its analgesic effect with cholinergic and opioid mechanisms (40). The results of the studies show that the sweet herb has its own analgesic effects through its flavonoids and steroids (41). Solanum melongena has been shown to have an analgesic effect by increasing blood carbohydrates and increasing levels of $\beta$-endorphins and environmental 
mechanisms (42). Cinnamomum zeylanicum exerts its analgesic effect by inhibiting Tumor necrosis factor and Cyclooxygenase-2, and also the production of prostaglandin as well as stimulating opioid receptors (27). The mechanisms by which Artemisia sieberi exerts its analgesic effects include inhibiting calcium release, blocking TRPA, inhibiting the synthesis of Nitric oxide, cytokines, and prostaglandin E2 (43). Besides, saffron has an analgesic effect by inhibiting NMDA receptors and NO synthesis (44). Studies show that the mechanisms of analgesic effect of Hypericum perforatum include inhibition of the Arachidonate 5-lipoxygenase and Cyclooxygenase-1 enzymes (33). Given the mechanism of the analgesic effect of the plants, it is suggested that the effect of each plant be identified and its mechanism of action be determined in order to produce an effective and potent analgesic agent.

Various compounds with their own mechanism actions might be involved in pain relieve activities of these plants, however, the role and the exact mechanism of each component should become clear. It should be noted that pain is accompanied with elevated oxidative stress and free radicals. Oxidative stress following induction of nociception results in elevation of free-radical which in turn usually imposes negative effects on pain (45). Hence, the medicinal plants presented in this article which have sufficient antioxidant activities should have acted, in part, through reducing oxidative stress. Brain is a susceptible organ to free radicals. An increase in free radicals may induce oxidative stress, because brain consumes high amount of oxygen. Also, brain contains high level of unsaturated fatty acids and low level of catalase which make this organ more susceptible to lipid peroxidation. This high level of susceptibility to oxidative stress prone the brain more than other organs to cellular damage or cell death (46). The brain oxidative stress enhances the chance of neurodegenerative disorders and pathogenesis conditions and other than pain $(47,48)$ increases some other psychoneurological diseases including depression (49, 50), Alzheimer's disease $(51,52)$ and Parkinson's disease $(53,54)$. Oxidative stress also enhances the chance of non-psycho-neurological diseases such as atherosclerosis $(55,56)$ cardiovascular $(57,58)$ and diabetes mellitus diseases $(59-62)$. As it was mentioned the pain itself is just a sign indicating other problems.

\section{Conclusion}

Hence, these plants which usually have multiple functions, other than having antinociceptive activities may also possess beneficial effects on other diseases of these patients.

\section{Acknowledgements}

The authors would like to acknowledge Research and Technology Deputy of Lorestan University of Medical Sciences for supporting this study.

\section{Conflicts of interest}

The authors declare no conflict of interest.

\section{References}

1. Ganong WF. Review of Medical Physiology. $22^{\text {nd }}$ ed. USA: Lange medical book; 2005. p. 142-47.

2. Lemke KA. Understanding the pathophysiology of perioperative pain. Can Vet J. 2004; 45(5):405-13.

3. Tutk DC, Meliack R. Handbook of pain assessment. $2^{\text {nd }}$ ed. USA: Guilford Press Inc.; 2001. p. 6-7.

4. Duck JA, BogenSchutz-Godwin MJ, duCellier J, Duke PAk. Hand book of medicinal herbs. $2^{\text {nd }} e d$. USA: CRC press; 2002. p. 640-41.

5. Shidata M, Ohkubo T, Inoki R. Modified formation test, characteristic biphasic pain response. Pain. 1990; 38:347-52. https://doi.org/10.1016/0304-3959(89)90222-4

6. Seminowicz DA, Moayedi M. The dorsolateral prefrontal cortex in acute and chronic pain. J Pain. 2017; 18(9):1027-35 https://doi.org/10.1016/j.jpain.2017.03.008

7. Institute of Medicine (US) Committee on Advancing Pain Research, Care, and Education. Relieving pain in America: A blueprint for transforming prevention, care, education, and research [Internet]. The National Academies Collection: Reports funded by National Institutes of Health. Washington DC; 2011. [cited 2019 May 1]. Available from: https://www.ncbi.nlm.nih.gov/pubmed/22553896

8. Ganong WF. Review of medical physiology. $21^{\text {st }}$ ed. New York, NY: McGraw-Hill Co; 2003. p. 215-22.

9. Shipton EA, Tait B. Flagging the pain: preventing the burden of chronic pain by identifying and treating risk factors in acute pain. Eur. J. Anaesthesiol. 2005; 22(6):405-12.

https://doi.org/10.1017/S0265021505000694

10. Merskey $\mathrm{H}$. Logic, truth and language in concepts of pain. Qual Life Res. 1994; 3(1):69-76. https://doi.org/10.1007/BF00433379

11. Dorland WA. Dorland's Illustrated Medical Dictionary. $30^{\text {th }}$ ed. Philadelphia: Saunders; 2003. p. 1351.

12. Howard L, Martin JB. Enteral and parenteral nutrition therapy. In: Fauci AS, Martin JB, Braunwald E, et al, editors. Harrison's Principles of Internal Medicine. $14^{\text {th }}$ ed. Vol. 1. New York, NY: McGraw-Hill Co; 1998. p. 5591.

13. Katzung BG. Basic \& Clinical Pharmacology. $10^{\text {th }}$ ed. USA: McGraw-Hill Companies; 2007. Vol. 31. p. 478-88.

14. Khorsand M. Antagonistic reactions of analgesic, antipyretic and anti-inflammatory drugs. Tehran: Khajah press; 1981. p. 5-16.

15. Abbasi N, Akhavan MM, Rahbar-Roshandel N, Shafiei $M$. The effects of low and high concentrations of luteolin on cultured human endothelial cells under normal and glucotoxic conditions: Involvement of integrin-linked kinase and cyclooxygenase-2. Phytothe 
Res.

2014; https://doi.org/10.1002/ptr.5128

28(9):1301-07

16. Abbasi N, Azizi Jalilian F, Abdi M, Saifmanesh M. A comparative study of the antimicrobial effect of Scrophularia striata Boiss. Extract and selective antibiotics against Staphylococcus aureus and Pesudomonas aeruginosa. J Med Plants 2007; 6(SUPPL 1): 10-18+69.

17. Bahmani M, Khaksarian M, Rafieian-Kopaei M, Abbasi N. Overview of the therapeutic effects of Origanum vulgare and Hypericum perforatum based on Iran's ethnopharmacological documents. J Clin Diagn Res. 2018; https://doi.org/10.7860/JCDR/2018/34177.11728

12(7):1-4

18. Shokri Z, Khoshbin M, Koohpayeh A, Abbasi N, Bahmani F, Rafieian-Kopaei M, et al. Thyroid diseases: Pathophysiology and new hopes in treatment with medicinal plants and natural antioxidants. Int J Green Pharm. 2018; 12(3):473-82.

19. Abbasi N, Mohammadpour S, Karimi E, Aidy A, Karimi P, Azizi M, et al. Protective effects of Smyrnium cordifolium Boiss essential oil on pentylenetetrazolinduced seizures in mice: Involvement of benzodiazepine and opioid antagonists. J Biolog Regulators Homeost Agents. 2017; 31(3):683-89.

20. Tajbakhsh M, Karimi A, Tohidpour A, Abbasi N, Fallah F, Akhavan MM. The antimicrobial potential of a new derivative of cathelicidin from Bungarus fasciatus against methicillin-resistant Staphylococcus aureus. J Microbiol. 2018; https://doi.org/10.1007/s12275-018-7444-5 56(2):128-37.

21. Bahmani M, Taherikalani M, Khaksarian M, RafieianKopaei M, Ashrafi B, Nazer M et al., The synergistic effect of hydroalcoholic extracts of Origanum vulgare, Hypericum perforatum and their active components carvacrol and hypericin against Staphylococcus aureus. Future Sci OA. 2019; 5(3):FSO371. eCollection 2019 Mar. https://doi.org/10.4155/fsoa-2018-0096

22. Shakiba Dastgerdi A, Rafieian-kopaei M, Jivad N, Sedehi M, Yousefi Darani M, Shirani F. Effect of hydroalcoholic extract of Anethum graveolens leaves on time response to pain stimuli in mice. J Shahrekord Univ Med Sci. 2013; 15(2):70-76.

23. Oryan S, Nasri S, Amin G, Kazemi-Mohammady SM M. Anti nociceptive and anti-inflammatory effects of aerial parts of Gundelia tournefortii L. on NMRI male mice. J Shahrekord Univ Med Sci. 2011; 12(4): 8-15.

24. Dashti Rahmatabadi MH, Anvari M, Rezai Sadrabadi M, Fallah Tafti H, Zanbagh S, et al. The effect of Solanum melongena L. hydro-alcoholic extract on chronic pain in male mice as compared with morphine. Iranian J Med Arom Plants. 2009; 25(1):3-7.

25. Kiasalari Z, Khalili M, Khoshnevisan F. Evaluation of the effect of sulfur grain hydroalcoholic extract on acute and chronic pain male rats. Semnan Uni Med Sci 2007; 8(4): 24:3-8.

26. AsadiShekari M, Sheibani V, Ebrahimi HA, Rismanichian M, Tajpari K. Evaluation of the analgesic effect of long-term consumption of aqueous extract of palm on the threshold of acute and chronic pain in adult male rats. Babol Uni Med Sci J 2007; 9(6):7-12.

27. DashtiRahmatabadi $\mathrm{MH}$, VahidiMehrjerdi AR, Pilevaran AA, Farzan F. Antinociceptive effect of cinnamon extract on formalin induced pain in rat. Yazd Uni Med Sci 2009; 17(9):57-66.
28. Morshedi A, DashtiRahmatabadi MH, DehghanHarati M, Bagherinasab MA, Salami AS. The effect of aqueousalcoholic extract of Artemisia (Artemisia sieberi Besser) on the reduction of neurogenic and inflammatory pain in mice. J Med Plants. 2011; 10(4):48-57.

29. Arbabian S, Izadi HR, Ghoshouni H, Shams J, Zardouz $\mathrm{H}$, Kamalinejad M, et al. Effect of aqueous extract of saffron (Crosus sativus) on chronic pain induced by formalin test in mice. Kosar Med J. 2009; 14(1):11-18.

30. Hejazian SH, Dashti MH, Salami A. The analgesic effect of alcoholic extract of Carum copticum (L.) C. B. Clarke on choronic pain in mice. Iranian J Med Aromatic Plants. 2008; 23(4):468-76.

31. Alibabaei Z, Shirani M, Kheiri S, Shirzad H, Taji F, Asgari S, et al. Effect of Euphorbia heliscopia extract on acute and chronic pain in mice. Babol Uni Med Sci. 2013; 13(4):14-18.

32. DashtiRahmatabadi MH, VahidiMehrjerdi AR, Panjalizadeh ME. Effect of water tartar extract on chronic pain In mice. J Med Plants. 2012; 11(2):136-44.

33. Khaksarian M, Javan M, Sonboli A, Motamedi F. Inhibition of acute and chronic pain in male rats by aqueous extract of Hypericum perforatum L. Yafteh J. 2004; 5(3):1-11.

34. Basim A, Hojjati MR, Alibabaei Z, Fathpoor H. Evaluating the analgesic effect of Cucurbita maxima Duch hydro-alcoholic extract in rats. J Shahrekord Univ Med Sci. 2014; 16(4):88-94.

35. Zarei M, Mohammadi S, Asgari Nematian M. Evaluation of the antinociceptive effect of methanolic extract of Passiflora caerulea L. in adult male rat. Yasouj Uni Med Sci. 2014; 19(1):56-66.

36. Anbari S, Estaji Z, Rastaqhi S. Assessment effect of Rosa damascena Juice aromatherapy on elderly chronic musculoskeletal pain in Sabzevar Retirement Clubs (Persian). Iranian J Ageing. 2018; 13(2):250-61. https://doi.org/10.32598/sija.13.2.250

37. Parvin N, Asgari A. The analgesic effect of ahlcholic extract of Tanacetum parthenium on pain in mice in formalin model. J Babol Uni Med Sci. 2012; 14(1):63-69.

38. Parvin N, Ansari Samani R, Shahinfard N, Reissi S, Alibabaie Z, Asgari A. Effect of alcoholic extract of Tanacetum parthenium on acute pain in rat. J Qazvin Uni Med Sci. 2012; 16(1):15-21.

39. Dashti Rahmatabadi MH, Anvari M. The effect of Solanum melongena L. hydro-alcoholic extract on chronic pain in male mice as compared with morphine. Iranian J Med and Arom Plants. 2009; 25(1):129-38

40. Kiasalari Z, Khalili M, Ashrafi M. Anti-nociceptive effect of alcoholic extract of henbane seed on the different phases of estrous cycle of female rats. J Gorgan Uni Med Sci. 2010; 11(4):1-7.

41. Babaei A, Pilehvarian AA, Shirani M, Kheyri Soleyman F, Taji F, Asgari A, et al. Effect of Euphorbia helioscopia on acetic acid-induced abdominal constrictions in Balb/C mice. Shahrekord Uni Med Sci J. 2010; 11(4):914.

42. Asadi Shekaari M, Sheibani V, Ebrahimi HA, Rismanchian M, Kalantari Pour TP, Afarinesh MR. Effect of long term consumption of aqueous date fruit extract on analgesia response in male rat. J Babol Uni Med Sci. 2008; 9(6):7-12. 
43. Dashti MH, Morshedi A, Dehghan AH, Bagherinasab MA, Salami AS. The Effect of Artemisia sieberi Besser on Infkammatory and Neurogenic Pain in Mice. J Med Plants. 2012; 40(4):57-49.

44. Zardooz H, Shams J, Izadi AH, Ghoshooni H, Arbabian $\mathrm{S}$, Kamalinejad M, et al. Effect of water extract of saffron (Crocus sativus) on chronic phase of formalin test in female mice. Kowsar J. 2009; 14(1):11-18.

45. Rame T, Gilbert AB. Update on the pathogenesis of complex regional pain syndrome: Role of oxidative stress. Canadian J Anesthesia. 2012; 59(9):875-88. https://doi.org/10.1007/s12630-012-9748-y

46. Eun-Joo S, Ji Hoon J, Yoon Hee C, Won-Ki K, Kwang-Ho $\mathrm{K}$, JaeHyung $\mathrm{B}$, et al. Role of oxidative stress in epileptic seizures. Neurochem Int. 2011; 59(2):122-37. https://doi.org/10.1016/j.neuint.2011.03.025

47. As'adi N, Kariman N. Herbal prevention and treatment of nipple trauma and/or pain in Iranian studies: a systematic review. J Herbmed Pharmacol. 2018; 7(3):168-75. https://doi.org/10.15171/jhp.2018.28

48. Tavakoli-Dastjerdi S, Motavasselian M, Emami SA, Mansourian M, Sahebkar A, Teimouri A. Efficacy of a combination of herbal gel versus topical diltiazem (2\%) in chronic anal fissure healing: a randomized double-blind clinical trial. J Herbmed Pharmacol. 2019; 8(2):139-45. https://doi.org/10.15171/jhp.2019.22

49. Rabiei Z, Gholami M, Rafieian-Kopaei M. Antidepressant effects of Mentha pulegium in mice. Bangladesh J Pharmacol. 2016; 11(3):711-15. https://doi.org/10.3329/bjp.v11i3.27318

50. Fathinezhad Z, Sewell RDE, Lorigooini Z, RafieianKopaei. Depression and Treatment with Effective Herbs. Current Pharmaceutical Design. 2019; 25:1-8. https://doi.org/10.2174/1381612825666190402105803

51. Beheshti S, Shahmoradi B. Therapeutic effect of Melissa officinalis in an amyloid- $\beta$ rat model of Alzheimer's disease. J Herbmed Pharmacol. 2018; 7(3):193-99. https://doi.org/10.15171/jhp.2018.31

52. Pirzad Jahromi G, Imani E, Nasehi M, Shahriari A. Effect of Achillea millefolium aqueous extract on memory deficit and anxiety caused by stroke in ovariectomized rats. J Herbmed Pharmacol. 2019; 8(2):153-59. https://doi.org/10.15171/jhp.2019.24

53. Zanganehnejad Z, Setorki M. Effect of Biarum carduchrum extract on brain tissue thiol level in rat model of 6-hydroxydopamine-induced Parkinson's disease. J Herbmed Pharmacol. 2018;7(3):136-40. https://doi.org/10.15171/jhp.2018.23

54. Sarrafchi A, Bahmani M, Shirzad H, Rafieian-Kopaei M. Oxidative stress and Parkinson's disease: new hopes in treatment with herbal antioxidants. Current Pharmac Design. 2016; 22(2):238-46. https://doi.org/10.2174/1381612822666151112151653
55. Moradi F, Sewell RDE, Lorigooini Z, Rafieian-Kopaei M. Immunosuppression-lipid metabolism interplay and medicinal plants in Atherosclerosis: A Review. Current Pharmac Design. 2018; 24:1-5. https://doi.org/10.2174/1381612824666180829105309

56. Islam D, Huque A, Sheuly, Mohanta LC, Das SK, Sultana A, et al. Hypoglycemic and hypolipidemic effects of Nelumbo nucifera flower in Long-Evans rats. J Herbmed Pharmacol. 2018; 7(3):148-54. https://doi.org/ 10.15171/jhp.2018.25

57. Shayganni E, Bahmani M, Asgary S, Rafieian-Kopaei M. Inflammaging and cardiovascular disease: Management by medicinal plants. Phytomed. 2016; 23(11):1119-26.

https://doi.org/10.1016/j.phymed.2015.11.004

58. Bahmani M, Sarrafchi A, Shirzad H, Asgari S, RafieianKopaei M. Cardiovascular toxicity of cyclooxygenase inhibitors and promising natural substitutes. Current Pharmac Design. 2017; 23(6):952-60. https://doi.org/10.2174/1381612822666161006144942

59. Rahimi-Madiseh M, Heidarian E, Kheiri S, RafieianKopaei M. Effect of hydroalcoholic Allium ampeloprasum extract on oxidative stress, diabetes mellitus and dyslipidemia in alloxan-induced diabetic rats. Biomed Pharmacoth. 2017; 86:363-67. https://doi.org/10.1016/j.biopha.2016.12.028

60. Rahimi-Madiseh M, Karimian P, Kafeshani M, RafieianKopaei M. The effects of ethanol extract of Berberis vulgaris fruit on histopathological changes and biochemical markers of the liver damage in diabetic rats. Iranian J Basic Med Sci. 2017; 20(5):552-56.

61. Nazarian-Samani Z, Sewell RD, Lorigooini Z, RafieianKopaei M. Medicinal plants with multiple effects on diabetes mellitus and its complications: A Systematic review. Current Diabetes Rep. 2018; 18(10):72. https:// doi.org/10.1007/s11892-018-1042-0

62. Rouhi-Boroujeni H, Heidarian E, Rouhi-Boroujeni H, Deris F, Rafieian-Kopaei M. Medicinal plants with Multiple Effects on Cardiovascular Diseases: A Systematic Review. Current Pharmace Design. 2017; 23(7):999-1015.

https://doi.org/10.2174/1381612822666161021160524

63. Khaksarian M, Gholami E, Alipour M, Sabooteh T, Asadi-Samani M. Investigation of the effects of the essence and extract of Allium jesdianum on the activity of COX-1 and COX-2 enzymes. Int J Advance Biotechnol Res. 2017; 8(2):1095-101.

64. Nadri S, Mahmoudvand H, Mahmoudvand H, Rashnoo M, Khaksarian M. Chemical composition, antinociceptive and acute toxicity of Pistacia atlantica fruit extract. Entomol Appl Sci Letters. 2018; 5(3):8-12. 